Ethiopian Journal of Environmental Studies \& Management 7(4): 371 - 378, 2014

ISSN:1998-0507

doi: http://dx.doi.org/10.4314/ejesm.v7i4.4

Submitted: March 21, 2014

Accepted: June 06, 2014

\title{
RELATIVE EFFECTIVENESS OF BIOGAS PRODUCTION USING POULTRY DROPPINGS AND SWINE DUNG
}

\author{
*ADENIRAN, K. A., YUSUF, K. O., IYANDA, M. O. AND ALO, 0. A. \\ Department of Agricultural and Biosystems Engineering, University of Ilorin, Ilorin, Nigeria
}

\begin{abstract}
Cow dung, poultry droppings and swine dung usually constitute refuse causing environmental pollution in Nigeria where these animals are reared. A study was conducted on the effectiveness of biogas production using poultry droppings and swine dung. The poultry droppings, swine dung and water were mixed in different ratios of 3:1:8 as sample $A, 1: 1: 4$ as sample $B$ and 1:3:8 as sample $C$. The study was carried out using Completely Randomised Design replicated two times. Six biogas digesters of the same size were used and each sample was loaded into the digester which was monitored for 13 days. The production of the biogas from the three samples started on the $6^{\text {th }}$ day at temperatures between $20^{\circ} \mathrm{C}$ and $40^{\circ} \mathrm{C}$ and the volume produced daily was measured by displacement method. Samples $B$ and $C$ attained peak production on the $11^{\text {th }}$ day but sample $A$ attained peak production on the $12^{\text {th }}$ day. Average biogas total volume production for samples $A, B$ and $C$ were $429.75 \mathrm{ml}, 440.3 \mathrm{ml}$ and $467.2 \mathrm{ml}$ respectively. The mean volumes of biogas produced from the three digesters were significantly different from one another. Thus Digester $C$ with the highest swine dung composition (1:3:8) was found to be more effective for producing biogas than poultry droppings (3:1:8).
\end{abstract}

Key Words: Biogas, biogas production, biogas digester, swine dung, poultry droppings

\section{Introduction}

Agricultural wastes from animals such as poultry droppings, cow dung, and swine dung usually produce obnoxious odour and environmental problems for the people living around the areas where such wastes are dumped. These animal wastes have been found to consist of exploitable gas and energy which can be obtained by a process called biomethanisation and the gas produced can be used as a source of energy or burning it directly for heating effect (Dupont and Accorsi, 2006). Biological process of treating solid and liquid organic residues that leads to formation of digestate and biogas production is called biomethanisation (Karellas et al., 2010). The negative impact of these waste products on the environment and man can be converted to useful materials in Nigeria as source of energy, biogas and organic fertilizer as pointed by (Karellas et al., 2010). Guendouz et al. (2010) pointed out that biogas is inexpensive, none polluting gas and can be used as a supplement for non renewable fossil energy. Biogas can be produced from almost all organic materials that could be decomposed or processed by anaerobic digestion (Crow, 2006). These include animal dung, sewage, landfills and industrial wastes. (Nagamani and Ramasamy, 2007) stressed that animal wastes are available and close to the point-of-use of the feedstock and economical for biogas production. The biogas can be used as a 
substitute for natural gas for cooking, heating and electricity. Digesters are effective at reducing problems of odours, pathogens and green house gas emission from animal waste or sewage sludge though the digesters cannot remove chemical contaminants in the waste (Lusk, 1998). Nigeria has been reported to have lost nearly 14,000 hectares of tropical forest per annum due to wood burning in form of charcoal (FAO, 1996). Exploitation of animal dung for production of biogas in Nigeria is rare and this can improve the economy of the country. The pioneer biogas plants are a $10 \mathrm{~m}^{3}$ biogas plants constructed in 1995 by the Sokoto Energy Research Centre (SERC) in Zaria and $18 \mathrm{~m}^{3}$ biogas plants constructed in 1996 at Ojokoro Ifelodun piggery farm, Lagos by the Federal Institute of Industrial Research Oshodi (FIIRO) Lagos (Zuru et al., 1998). Eze et al. (2007) reported that if all the livestock waste in Nigeria are recovered and utilized to produce methane, approximately $7-10 \%$ of the total energy consumption could be replaced. Eze et al., (2007) reported the Nigeria's biogas potentials (minimum value) from solid waste and livestock excrements in 1999 is about $1.382 \times 10^{9} \mathrm{~m}^{3}$ of biogas/year or an annual equivalent of 4.81 million barrels of crude oil. The abundant availability of animal manure in Nigeria (particularly from poultry enterprises), which could cause health hazards during decay could be turned to biogas for utilization by the rural communities and later in future be commercialised for sale to urban dwellers. Ojolo et al., (2007) conducted a comparative study of biogas production from poultry droppings, cattle dung, and kitchen under the same operating conditions. Poultry droppings produced more biogas than cow dung and kitchen wastes. Uzodinma et al., (2011) investigated biogas fuel production from blends of biological wastes such as pumpkin pod, cow dung and swine dung with maize bract. Results indicated that the low flammable biogas from the maize bract waste could be enhanced significantly by blending with cow and swine dung. Ofoefule et al., (2010) investigated the production potential of paper waste and its blend with cow dung in the ratio $1: 1$. The study showed that paper waste is a very good feedstock for biogas production. It also indicates that blending paper waste with cow dung or any other animal waste will give sustained gas flammability throughout the digestion period of the waste since animal wastes are good starters for poor biogas producing wastes. Results indicated that the low flammable biogas from the maize bract waste can be enhanced significantly by blending with cow and swine dung. Adeniran et al., (2014) reported that poultry wastes produced more biogas than cow dung. The main objective of this study was to determine the relative effectiveness of biogas production from different feedstock composition of 3:1:8, 1:1:4 and 1:3:8 (poultry droppings: swine dung: water).

\section{Materials and Methods}

An anaerobic digester is equipment used for the production of biogas from mixture of gases created by methanogenic bacteria which break down the organic matter in an anaerobic condition and nutrient rich in substrates can be used as fertilizers and fish meal. The digester is often also referred to as biogas chamber, biogas plant or an anaerobic reactor. The materials used for the biogas production in this study were poultry droppings; swine dung and water were collected from Tanke area, Ilorin (Figure 1). The study was conducted in the Department of Agricultural and Biosystems Engineering, University of Ilorin, Ilorin, Nigeria. The study site is located between Latitude $8^{\circ} 24^{\prime}$ $\mathrm{N}$ and $8^{\circ} 36^{\prime} \mathrm{N}$ and Longitude $4^{\circ} 10^{\prime} \mathrm{E}$ and $4^{\circ}$ $36^{\prime} \mathrm{E}$ as shown in Figure 1. It has an 
approximate area of about $32,500 \mathrm{~km}^{2}$ (Fadeyi et al., 2009). It is situated in the North central of Nigeria at about $302 \mathrm{~km}$ North of Lagos and $475 \mathrm{~km}$ south of Abuja (FCT). The climate of Ilorin is characterized by both wet and dry seasons. The mean monthly temperatures are very high varying from $25^{\circ} \mathrm{C}$ to $28.9^{\circ} \mathrm{C}$ (Ajadi et al., 2011). Ilorin with an elevation of about $340 \mathrm{~m}$ above

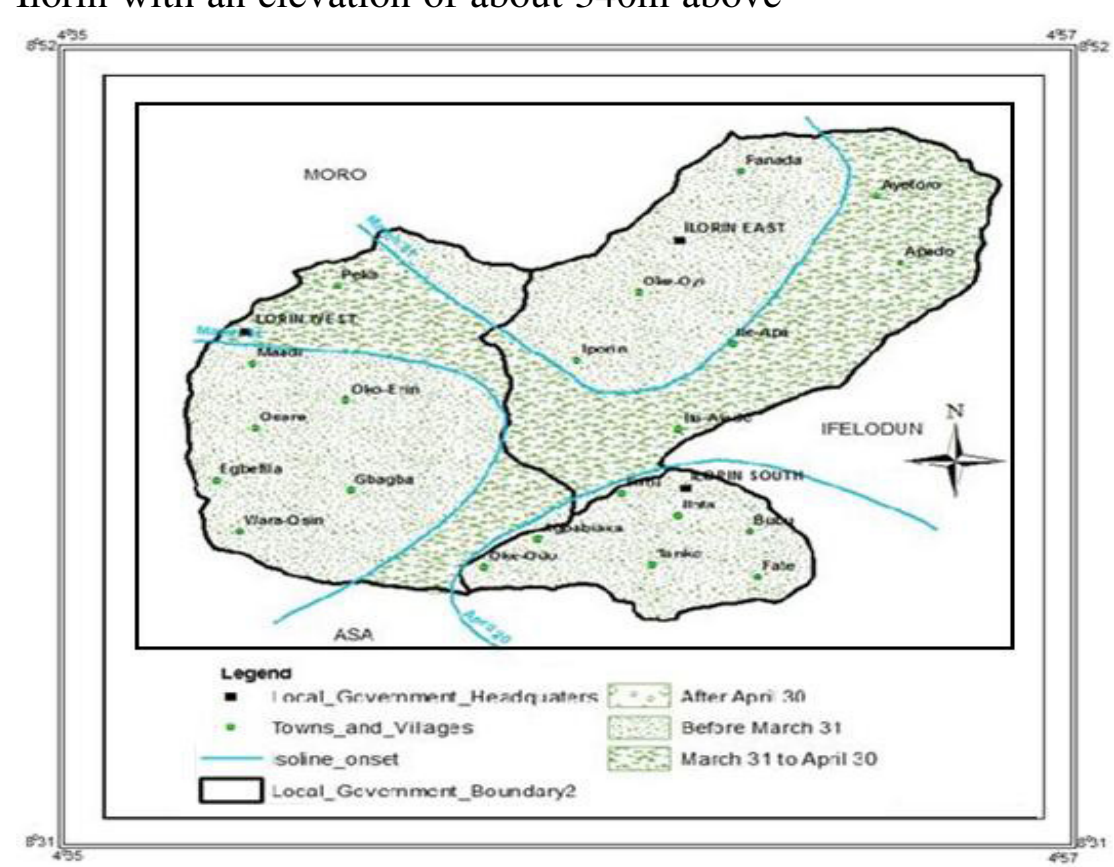

Figure 1: Location Map of the study area (Ajadi et al., 2011)

The samples $\mathrm{A}, \mathrm{B}$ and $\mathrm{C}$ were the treatments fed into the digester at three different mix ratios of $3: 1: 8,1: 1: 4$ and 1:3:8 respectively. The mixing ratio of the sample A contained $1.5 \mathrm{~kg}$ of poultry droppings, 0.5 $\mathrm{kg}$ of swine dung and $4.0 \mathrm{~kg}$ of water. Sample B contained $1.0 \mathrm{~kg}$ of poultry, $1.0 \mathrm{~kg}$ of swine dung and $4.0 \mathrm{~kg}$ of water. Sample C contained $0.5 \mathrm{~kg}$ of poultry droppings, $1.5 \mathrm{~kg}$ of swine dung and $4 \mathrm{~kg}$ of water. Each treatment was replicated twice. Based on the composition of animal waste with water as a solvent for mixing the two organic matters, Sample A had $75 \%$ poultry droppings and $25 \%$ swine dung. Sample B contained 50\% poultry droppings and 50\% swine dung. Sample C contained $25 \%$ poultry droppings mean sea level falls within the Southern Guinea Savannah Ecological Zone of Nigeria. The total annual rainfall in the area is about $1200 \mathrm{~mm}$ (Olaniran, 2002). The rainfall pattern is bimodal distribution. The rainy season starts around March, with a short dry spell in July. The long dry spell begins in November and ends in March.

and $75 \%$ swine dung. Six digesters of the same design and capacity were used for this study. The digesters labeled $A_{1}$ and $A_{2}$ were used for samples $A_{1}$ and $A_{2}$, digesters $B_{1}$ and $\mathrm{B}_{2}$ for samples $\mathrm{B}_{1}$ and $\mathrm{B}_{2}$, and digesters $\mathrm{C}_{1}$ and $C_{2}$ for samples $C_{1}$ and $C_{2}$. The slurry was prepared in the slurry tank of the digester by addition of water to the animal waste in the right proportion. The volume of biogas produced in the digester was measured by the volume of water displaced in the scrubber by the gas and recorded as the biogas produced. Statistical analysis was carried out using Duncan's multiple tests.

\section{Results and Discussion}

The quantity of biogas produced daily from mixing ratio of poultry droppings, swine 
dung and water as samples A, B and C for a period of 13 days were shown in Tables 1, 2, and 3. The biogas production from the digester started on the $6^{\text {th }}$ day of the experiment from the three samples. The volume of biogas produced was highest with sample $\mathrm{C}$ which contained high percentage content of swine dung with $75 \%$ and $25 \%$ of poultry droppings, followed by sample B that contained $50 \%$ poultry droppings and $50 \%$ swine dung. Sample A which contained the lowest content of swine dung of $25 \%$ and $75 \%$ poultry droppings produced the least volume of biogas. This shows that swine dung has a better potential of generating biogas than the poultry droppings as shown in Tables 1, 2 and 3. Average biogas production from samples $\mathrm{A}, \mathrm{B}$ and $\mathrm{C}$ were $429.3 \mathrm{ml}, \quad 440.3 \mathrm{ml}$ and $467.2 \mathrm{ml}$ respectively. The mean volumes of biogas produced from the three digesters were as shown in Fig 2. The result of the estimated marginal mean test presented in Table 4 revealed that digester $\mathrm{C}$ produced higher mean values of biogas in all the days of the experiment. Digester B was also seen to produce more than digester $\mathrm{A}$ in terms of biogas production. Table 5 showed the effect of types of digester and days of the experiment using two ways analysis of variance. The analysis reveals that both types of digester and days of experiment were significant at $95 \%$ confidence level. The hypothesis of equal mean treatment effect of digester and days of experiment was therefore rejected. This probably implies that the days of the experiment did not record the same mean values of biogas production. This assertion was confirmed using Duncan's multiple tests for days, as seen in Table 6 . The table indicates that if digester was not the case, then day eleven generally appear to record the highest mean value of biogas which was significantly higher than that recorded from day twelve and day thirteen.
Days ten, twelve and thirteen produced relatively the same quantity of biogas but were statistically higher compare to the yield from day six, seven and eight respectively. The three digesters were filled using different composition of swine and poultry wastes. These digesters proved to be statistically different from each other in term of swine dung and poultry droppings composition as shown in Tables 1, 2 and 3. Further investigation using Duncan's multiple tests showed that Digester $C$ produced the highest mean biogas of $58.4 \mathrm{ml}$ and this value was significantly higher than that produced from the two other digesters A $(53.72 \mathrm{ml})$ and B $(55.11 \mathrm{ml})$ as shown in Table 7 . This is may be due to higher carbon-nitrogen ration in swine dung as compared to poultry droppings. The higher biogas production for swine dung could also be attributed to the available nutrients in the droppings. The higher volume gas produced by Digester C may be due to higher nitrogen content in poultry droppings as compared to other feed stocks (Ojolo et al., 2007). Also, the higher biogas production from swine dung could also be attributed to large amount of available nutrients presented in the dung (Adeniran et al., 2014). According to Hill and Brath (1997) substrates for biogas production should contain adequate amount of carbon, oxygen, hydrogen, nitrogen, sulphur, phosphorous, potassium, calcium, magnesium and a number of trace elements.

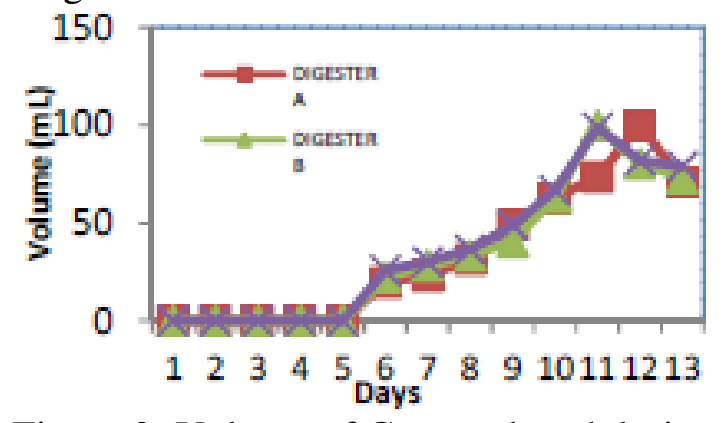

Figure 2: Volume of Gas produced during the study 


\section{Conclusions}

Waste products from animals such as poultry droppings and swine dung that normally constitute refuse in the areas where they are dumped and on the farm where the animals are reared thereby creating environmental pollution could be converted to useful materials like biogas and organic fertilizer. Biogas from animal droppings/dung does not contain odour and free from pathogen. The study revealed that swine dung can produce more biogas than the poultry droppings.

Table 1: Volume of biogas produced using sample A with $25 \%$ swine dung and $75 \%$ poultry droppings

\begin{tabular}{llll}
\hline \multirow{2}{*}{ Day } & \multicolumn{2}{l}{ Volume of biogas produced in sample $\mathrm{A}(\mathrm{ml})$} & $\begin{array}{l}\text { Mean volume of } \\
\text { biogas }(\mathrm{ml})\end{array}$ \\
\cline { 2 - 4 } & $\mathrm{A}_{1}$ & $\mathrm{~A}_{2}$ & 0.00 \\
1 & 0.00 & 0.00 & 0.00 \\
2 & 0.00 & 0.00 & 0.00 \\
3 & 0.00 & 0.00 & 0.00 \\
4 & 0.00 & 0.00 & 0.00 \\
5 & 0.00 & 0.00 & 19.65 \\
6 & 19.90 & 19.40 & 23.00 \\
7 & 23.10 & 22.90 & 31.25 \\
8 & 30.60 & 31.90 & 48.90 \\
9 & 49.20 & 48.60 & 62.60 \\
10 & 62.60 & 62.60 & 73.60 \\
11 & 73.30 & 73.90 & 99.80 \\
12 & 99.90 & 99.70 & 70.95 \\
13 & 70.60 & 71.30 & 429.75 \\
\hline Total & 429.20 & 430.30 & \\
\hline
\end{tabular}

Table 2: Volume of biogas produced using sample B with $50 \%$ swine dung and $50 \%$ poultry droppings

\begin{tabular}{llll}
\hline Day & \multicolumn{2}{l}{ Volume of biogas produced in sample B $(\mathrm{ml})$} & $\begin{array}{l}\text { Mean volume of } \\
\text { biogas }(\mathrm{ml})\end{array}$ \\
\cline { 2 - 3 } & $\mathrm{B}_{1}$ & $\mathrm{~B}_{2}$ & 0.00 \\
2 & 0.00 & 0.00 & 0.00 \\
3 & 0.00 & 0.00 & 0.00 \\
4 & 0.00 & 0.00 & 0.00 \\
5 & 0.00 & 0.00 & 0.00 \\
6 & 0.00 & 0.00 & 22.25 \\
7 & 22.60 & 21.90 & 28.35 \\
8 & 28.50 & 28.20 & 33.10 \\
9 & 33.30 & 32.90 & 40.40 \\
10 & 40.10 & 40.70 & 63.40 \\
11 & 63.30 & 63.50 & 99.75 \\
12 & 99.60 & 99.90 & 80.25 \\
13 & 80.60 & 79.90 & 72.80 \\
\hline Total & 73.30 & 72.30 & 440.30 \\
\hline
\end{tabular}


Table 3: Volume of biogas produced using sample $\mathrm{C}$ with $75 \%$ swine dung and $25 \%$ poultry droppings

\begin{tabular}{llll}
\hline Day & \multicolumn{2}{l}{ Volume of biogas produced in sample $\mathrm{C}(\mathrm{ml})$} & $\begin{array}{l}\text { Mean } \\
\text { biogas }(\mathrm{ml})\end{array}$ \\
\cline { 2 - 4 } & $\mathrm{C}_{1}$ & $\mathrm{C}_{2}$ & 0.00 \\
& 0.00 & 0.00 & 0.00 \\
2 & 0.00 & 0.00 & 0.00 \\
3 & 0.00 & 0.00 & 0.00 \\
4 & 0.00 & 0.00 & 0.00 \\
5 & 0.00 & 0.00 & 25.60 \\
6 & 25.30 & 25.90 & 30.00 \\
7 & 30.10 & 29.90 & 36.40 \\
8 & 36.60 & 36.20 & 48.75 \\
9 & 48.10 & 49.40 & 66.60 \\
10 & 66.70 & 66.50 & 98.90 \\
11 & 99.50 & 98.30 & 81.95 \\
12 & 82.30 & 81.60 & 79.00 \\
13 & 79.30 & 78.70 & 467.20 \\
\hline Total & 467.90 & 466.50 & \\
\hline
\end{tabular}

Table 4: Marginal means of biogas production from the digesters for days 6 to 13 95\% Confidence Interval

\begin{tabular}{lllllll} 
Days & Digesters & Mean & Std. Error & Lower Bound & Upper Bound & Sig \\
\hline Day 6 & Digester A & 20.500 & 4.670 & 10.483 & 30.517 & \\
& Digester B & 21.819 & 4.670 & 11.802 & 31.836 & \multirow{2}{*}{0.001} \\
& Digester C & 25.181 & 4.670 & 15.164 & 35.198 & \\
Day 7 & Digester A & 25.117 & 4.670 & 15.100 & 35.134 & \\
& Digester B & 26.435 & 4.670 & 16.418 & 36.453 & \multirow{2}{*}{0.233} \\
& Digester C & 29.798 & 4.670 & 19.781 & 39.815 & \\
Day 8 & Digester A & 31.583 & 4.670 & 21.566 & 41.600 & \\
& Digester B & 32.902 & 4.670 & 22.885 & 42.919 & 0.235 \\
& Digester C & 36.265 & 4.670 & 26.247 & 46.282 & \\
Day 9 & Digester A & 44.017 & 4.670 & 34.000 & 54.034 & \\
& Digester B & 45.335 & 4.670 & 35.318 & 55.353 & \multirow{2}{*}{ Day 10 } \\
& Digester C & 48.698 & 4.670 & 38.681 & 58.715 & \\
& Digester A & 62.200 & 4.670 & 52.183 & 72.217 & \\
& Digester B & 63.519 & 4.670 & 53.502 & 73.536 & \\
Day 11 & Digester C & 66.881 & 4.670 & 56.864 & 76.898 & 0.003 \\
& Digester A & 88.750 & 4.670 & 78.733 & 98.767 & \\
& Digester B & 90.069 & 4.670 & 80.052 & 100.086 & \\
Day 12 & Digester C & 93.431 & 4.670 & 83.414 & 103.448 & 0.001 \\
& Digester A & 85.333 & 4.670 & 75.316 & 95.350 & \\
& Digester B & 86.652 & 4.670 & 76.635 & 96.669 & \multirow{2}{*}{ D. } \\
Day 13 & Digester C & 90.015 & 4.670 & 79.997 & 100.032 & 0.001 \\
& Digester A & 72.250 & 4.670 & 62.233 & 82.267 & \\
& Digester B & 73.569 & 4.670 & 63.552 & 83.586 &
\end{tabular}


Table 5: Two way analysis of variance for the digesters

\begin{tabular}{llllll}
\hline Source & Sum of Squares & df & Mean Square & F & Sig. \\
\hline Intercept & 74509.898 & 1 & 74509.898 & 1423.252 & .000 \\
Days & 15443.042 & 7 & 2206.149 & 42.141 & .000 \\
Digesters & 93.226 & 2 & 46.613 & .890 & .433 \\
Error & 732.926 & 14 & 52.352 & & \\
Total & 90779.093 & 24 & & & \\
\hline
\end{tabular}

Table 6: Duncan's multiple range tests for the days

\begin{tabular}{|c|c|c|c|c|c|}
\hline & & Subset & & & \\
\hline Days & $\mathrm{N}$ & 1 & 2 & 3 & 4 \\
\hline$\overline{\text { Day6 }}$ & 3 & 22.5000 & & & \\
\hline Day7 & 3 & 27.1167 & & & \\
\hline Day8 & 3 & 33.5833 & 33.5833 & & \\
\hline Day9 & 3 & & 46.0167 & & \\
\hline Day10 & 3 & & & 64.2000 & \\
\hline Day13 & 3 & & & 74.2500 & \\
\hline Day12 & 3 & & & & 87.3333 \\
\hline Day11 & 3 & & & & 90.7500 \\
\hline Sig. & & .096 & .054 & .111 & .572 \\
\hline
\end{tabular}

Table 7 Duncan multiple range test for digesters

\begin{tabular}{llcccc}
\hline Digester & $\mathrm{N}$ & & \multicolumn{2}{c}{ Subsets } & 3 \\
\hline Digester A & 8 & 53.7188 & & & \\
Digester B & 8 & & 55.0375 & \\
Digester C & 8 & & & 58.4000 \\
Sig. & & .239 & .239 & .239 \\
\hline
\end{tabular}

\section{References}

Adeniran, K.A., Ahaneku, I.E., Itodo, I. N. and Rohjy, H.A. (2014). Relative Effectiveness of Biogas Production using Poultry Wastes and Cow Dung. Agricultural Engineering International: The Journal of the CIGR, 16(1): 126132.

Ajadi, B. S., Adeniyi, A. and Afolabi, M. T. (2011). Impact of Climate on Urban Agriculture: Case Study of Ilorin City, Nigeria. Global Journals Inc. (USA) Global Journal of Human Social Science, Volume 11, Issue 1.

Dupont, L., and Accorsi, L.A. (2006). "Explosion characteristics of synthesised biogas at various temperatures", Journal of Hazardous Materials, 136: 520-525.

Eze, I.S., Anyanwu, C.N., Oparaku, O.U. and Okoye, C.O.B. (2007). 'Animal Manure: A Resource or a Waste?': $37^{\text {th }}$ Annual Conference of Nigerian Society of Chemical Engineers. www.nschef.org, Accessed July, 2012. Resource or a Waste?': $37^{\mathrm{th}}$ Annual Conference of Nigerian Society of Chemical Engineers. www.nschef.org, Accessed July, 2012.

Fadeyi, A., Nwabuise, C., Adegboro, B., Akanbi, A. A., Fowotade, A. and Odimayo, M. S. (2009). Apparent Rarity of Entamoeba Histolytica and Other Intestinal Parasites in Acute and 
Persistent Diarrhoertic Patients Attending Ilorin Hospitals: Time for ELISA Antigen Based Amoebiasis Diagnosis; European Journal of Scientific Research, 31(3): 288- 397.

Food and Agricultural Organisation of the United Water (FAO) (1996): A System approach to Biogas Technology, Food and Agricultural Organisation, Rome. (FAO/CMS, 1996; pp64)

Guendouz, J., Buffière, P., Cacho, J., Carrère, M., and Delgènes, J.P. (2010). "Dry anaerobic digestion in batch mode: Design and operation of a laboratoryscale, completely mixed reactor", Waste Management, Article in press (4 pages).

Hill, J. and Brath, A (1997). 'A Dynamic Model for Simulation of Animal Waste Digestion': Water Pollution Control, Canton, Ohio. www.hach-lange.com.

Karellas, S., Boukis, I. and Kontopoulos, G., (2010) "Development of an investment decision tool for biogas production from agricultural waste", Renewable and Sustainable Energy, 14: 1273-1282.

Lusk, P. (1998). Methane Recovery from Animal Manures: a Current Opportunities Casebook, $3^{\text {rd }}$ edition NREL/SR-25145. Prepared by Resource Development Associates, Washington, DC, under contract to the National Renewable Energy Laboratory. Golden, CO. pages 1-5.

Ofoefule, A.U., Nwankwo, J. and Ibeto, C.N. (2010). Biogas Production from Paper
Waste and its blend with Cow dung, Advances in Applied Science Research, 1 (2): 1-8.

www.pelagiaresearchlibrary.com

Ojolo, S.J., Oke, S.A., Animasahun, K. and Adesuyi, B.K. (2007). Utilization of Poultry, Cow and Kitchen Wastes For Biogas Production: A Comparative Analysis. Iran. J. Environ. Health. Sci. Eng., 4(4): 223-228.

Olaniran, O. J. (2002). The Problems in the Measurement of Rainfall: An Experiment at Ilorin, Nigeria, Weather, 37(7): $201-204$.

Nagamani, B. and Ramasamy, K. (2007). 'Biogas Production Technology: An Indian Perspective, Tamil Nadu Agricultural University, India. www.ias.ac.in/currsci/jul10/articles13.ht m.

Zuru, A.A. ; Saidu, H; Odum E. A and Onuorah O.A., (1998). A comparative study of Biogas production from horse, goat, and sheep dung. Nigerian. $J$. Renewable Energy, 6(1-2): 43 - 47.

Uzodinma, E.O., Ofoefule, A.U. and Enwere, N. J. (2011). Optimization of biogas fuel production from maize (Zea mays) bract waste: Comparative study of biogas production from blending maize bract with biogenic wastes. Am. J. Food. Nutr., 1(1): 1-6.

http://www.scihub.org/AJFN 